\title{
THE
}

2005

\section{A New Model to Estimate Daily Energy Expenditure for Wintering Waterfowl}

Richard A. McKinney

Scott R. McWilliams

University of Rhode Island, srmcwilliams@uri.edu

Follow this and additional works at: https://digitalcommons.uri.edu/nrs_facpubs

Terms of Use

All rights reserved under copyright.

\section{Citation/Publisher Attribution}

McKinney, R. A., \& McWilliams, S. R. (2005). A New Model to Estimate Daily Energy Expenditure for Wintering Waterfowl. Wilson J. of Ornithology, 117(1), 44-55. doi: 10.1676/04-060

Available at: https://doi.org/10.1676/04-060

This Article is brought to you for free and open access by the Natural Resources Science at DigitalCommons@URI. It has been accepted for inclusion in Natural Resources Science Faculty Publications by an authorized administrator of DigitalCommons@URI. For more information, please contact digitalcommons-group@uri.edu. 


\title{
BioOne COMPLETE
}

\section{A NEW MODEL TO ESTIMATE DAILY ENERGY EXPENDITURE FOR WINTERING WATERFOWL}

\author{
Authors: R. I. C. H. A. RD A. McKINNEY, and S. C. O. T. T R. \\ McWILLIAMS
}

Source: The Wilson Bulletin, 117(1) : 44-55

Published By: Wilson Ornithological Society

URL: https://doi.org/10.1676/04-060

BioOne Complete (complete.BioOne.org) is a full-text database of 200 subscribed and open-access titles in the biological, ecological, and environmental sciences published by nonprofit societies, associations, museums, institutions, and presses.

Your use of this PDF, the BioOne Complete website, and all posted and associated content indicates your acceptance of BioOne's Terms of Use, available at www.bioone.org/terms-of-use.

Usage of BioOne Complete content is strictly limited to personal, educational, and non-commercial use. Commercial inquiries or rights and permissions requests should be directed to the individual publisher as copyright holder.

BioOne sees sustainable scholarly publishing as an inherently collaborative enterprise connecting authors, nonprofit publishers, academic institutions, research libraries, and research funders in the common goal of maximizing access to critical research. 


\title{
A NEW MODEL TO ESTIMATE DAILY ENERGY EXPENDITURE FOR WINTERING WATERFOWL
}

\author{
RICHARD A. MCKINNEY ${ }^{1,3}$ AND SCOTT R. MCWILLIAMS ${ }^{2}$
}

\begin{abstract}
Current models to estimate daily energy expenditure (DEE) for free-living birds are limited to either those that use fixed thermoregulatory costs or those that more accurately estimate thermoregulatory costs, but require extensive and often logistically difficult measurements. Here, we propose a model based on basal metabolic rate (BMR), activity budgets, and site-specific energetic costs of thermoregulation that requires only simple measures of ambient temperature and wind speed to provide estimates of DEE. We use the model to calculate the DEE of Buffleheads (Bucephala albeola) wintering at six habitats that afford differing degrees of protection from exposure within Narragansett Bay, Rhode Island. Bufflehead activity budget data collected during the winters of 2001-2002 and 2002-2003, along with average temperatures and wind speeds at the sites, were used to calculate DEE that ranged from 46.9 to $52.4 \mathrm{~kJ} / \mathrm{hr}$ and increased with increasing wind speed. The energetic cost of thermoregulation composed as much as $28 \%$ of total DEE and increased with wind speed. Our DEE values were $13.4 \%$ higher, and thermoregulatory costs were up to $2 \times$ higher than those calculated using an existing model that incorporates fixed thermoregulatory costs. We also saw an increase in feeding activity with increasing wind speed; sensitivity analysis of the effects of wind speed and feeding activity showed that a $1 \mathrm{~m} / \mathrm{sec}$ increase in wind speed at our sites increased DEE by $2.5 \%$, whereas a corresponding increase in feeding activity increased DEE by $4.5 \%$. This suggests that in temperate winter habitats, increased feeding activity may have a greater impact on Bufflehead DEE than wind exposure. Site-specific model estimates of DEE could also provide additional insight into the relative contribution of environmental conditions and changes in waterfowl behavior to DEE. Received 27 May 2004, accepted 12 January 2005.
\end{abstract}

The daily energy expenditure (DEE) of a species is the sum of basal metabolic rate (BMR), thermoregulatory requirements, and the energetic cost of daily activities such as feeding, locomotion, and social behaviors. Quantitative assessments of the daily activities of wintering waterfowl have been used both to identify important habitats for these species and to assess their response to changes in habitat quality (Fredrickson and Drobney 1979, Brodsky and Weatherhead 1985a, Baldassarre et al. 1988, Paulus 1988). Waterfowl activity budgets may be influenced by habitat type (Turnbull and Baldassarre 1987, Rave and Baldassarre 1989) and site characteristics such as food abundance, protection from exposure, and level of disturbance (Nilsson 1970, Jorde et al. 1984, Paulus 1984, Quinlan and Baldassarre 1984, Brodsky and Weatherhead 1985b, Miller 1985). Changes in waterfowl activity may also be tied to changes in DEE that result

\footnotetext{
${ }^{1}$ U.S. Environmental Protection Agency, Office of Research and Development, National Health and Environmental Effects Research Lab., Atlantic Ecology Div., 27 Tarzwell Dr., Narragansett, RI 02882, USA.

${ }^{2}$ Dept. of Natural Resources Science, Univ. of Rhode Island, Kingston, RI 02881, USA.

${ }^{3}$ Corresponding author; e-mail: mckinney.rick@epa.gov
}

from the influence of habitat characteristics. For example, increased exposure to cold and wind may increase thermoregulatory energy costs, and therefore require increased feeding to offset higher energetic costs (Bennett and Bolen 1978, Hickey and Titman 1983). Models that allow comparison between the energetic costs of thermoregulation and specific waterfowl behaviors could be used to determine the relative magnitude of these costs, and may also provide insight into the effects of habitat quality on the DEE of resident waterfowl.

Traditional measures of DEE for birds from time-activity budgets use multiples of BMR to estimate energetic costs of activities, but may differ in how the thermoregulatory component of DEE is estimated (Weathers et al. 1984). Early estimates of DEE included either a fixed cost of thermoregulation or one based solely on ambient temperature (Kendeigh 1949, Schartz and Zimmerman 1971, Koplin et al. 1980). Models subsequently evolved to include a means to more accurately estimate thermoregulatory costs, but only by the extensive measurement of many variables (e.g., whole-body thermal resistance, forced-convective resistance), some of which may be logistically difficult to obtain for free-living 
wildlife (Pearson 1954, Stiles 1971, Walsberg 1977). Weathers et al. (1984) proposed the use of standard operative temperature, or indices that allow single-number representations of complex thermal environments, to overcome some of these difficulties. However, while providing a much more rigorous estimate of thermoregulatory costs, this approach is limited by the need for the construction and calibration of taxidermic mounts, and may be best suited for aviary or well-controlled field applications. To date, researchers estimating DEE for free-living birds using published activity-based models are limited to either those that use fixed thermoregulatory costs or those that more accurately estimate thermoregulatory costs, but at the expense of extensive and often logistically difficult measurements of many variables.

Previous studies estimating DEE for wintering waterfowl have employed models that use factorial increases of BMR and that assume a fixed cost of thermoregulation (Wooley and Owen 1978, Albright et al. 1983, Morton et al. 1989, Parker and Holm 1990). For wintering waterfowl in northern areas exposed to low temperatures and high winds, thermoregulation may compose as much as $80 \%$ of daily energetic costs (Ettinger and King 1980, Walsberg 1983). These costs may vary between wintering habitats because of differing degrees of protection from exposure to wind and cold (Porter and Gates 1969, Goldstein 1983, Bakken 1992). If estimates of DEE are to be useful in assessing habitat quality for wintering waterfowl, they need to include some measure of the energetic cost of thermoregulation based on local environmental conditions.

Here, we present an activity-based model that includes habitat-specific measures of thermoregulatory costs to estimate DEE of waterfowl in different habitats. Our model requires only simple measures of ambient temperature and wind speed, along with waterfowl activity budgets and morphological measurements. Thermoregulatory costs are calculated by using heat loss via conduction and convection as a function of temperature and wind speed to estimate the metabolic heat production required to maintain body temperature (Birkebak 1966, Goldstein 1983). Because of the ability to estimate site-specific DEE based on local conditions, the model may be useful in evaluating habitats that provide differing degrees of protection from high winds and extreme temperatures. Model estimates could also be used to provide insight into the relative contribution of environmental conditions and differences in waterfowl behavior to changes in DEE.

In this study, we used our model to estimate the DEE of Buffleheads (Bucephala albeola) at six wintering habitats in Narragansett Bay, Rhode Island, that afford differing degrees of protection from exposure to wind and cold temperatures. Our specific objectives were to (1) compare estimates of DEE obtained using our model with those obtained using a previously published model that incorporates a fixed cost of thermoregulation, and (2) examine changes in DEE across the sites and determine the relative contribution of wind speed and waterfowl feeding behavior to changes in DEE.

\section{METHODS}

DEE site-specific thermoregulation model.-Our model incorporating site-specific thermoregulatory costs into DEE for wintering Buffleheads (hereafter, SST model) consists of (1) a thermoregulatory component $\left(\mathrm{EE}_{\text {Thermoreg }}\right)$ - an estimate of the metabolic heat production required to balance heat loss from the bird to the environment through conduction and convection, and (2) an activity component $\left(\mathrm{EE}_{\text {Activity }}\right)$ - an estimate of additional energetic costs resulting from specific daily activities of wintering Bufflehead expressed as multiples of basal metabolic rate (BMR). We sum these components to arrive at an estimated DEE. In our model, metabolic heat production includes resting energy expenditure in a thermoneutral environment (i.e., BMR) and the additional energy expenditure required to maintain thermal equilibrium. The model uses average temperatures and wind speeds that coincide with activity budget sampling at the sites; DEE is reported in $\mathrm{kJ} / \mathrm{hr}$.

Basal metabolic rates were estimated from those of 16 North American duck species summarized in McNab (2003). A plot of BMR versus body mass for these species gave the relation: $\mathrm{BMR}=4.05 \mathrm{M}^{0.79}$, where $\mathrm{BMR}$ is basal metabolic rate in $\mathrm{ml} \mathrm{O}_{2} / \mathrm{hr}$, and $\mathrm{M}$ is body mass in $\mathrm{g}$. Estimates of BMR were con- 
verted to $\mathrm{kJ} / \mathrm{hr}$ using a conversion factor of $18.8 \mathrm{~kJ} / \mathrm{L} \mathrm{O}_{2}$, derived from the average composition of the Bufflehead's winter diet (Schmidt-Nielsen 1997). Body mass was approximated at $450 \mathrm{~g}$ for males and $325 \mathrm{~g}$ for females (Gauthier 1993).

Before calculating metabolic heat production, we first determined when this component of a Bufflehead's DEE is necessary by comparing ambient temperature with their lower critical temperature, or the temperature below which metabolic heat production is required to maintain body temperature (Schmidt-Nielsen 1997). Lower critical temperature (LCT) was estimated by the empirical relation: LCT $=47.2 \mathrm{M}^{-0.18}$, where LCT is in ${ }^{\circ} \mathrm{C}$, and $\mathrm{M}$ is body mass in $\mathrm{g}$ (Kendeigh 1977). We compared effective ambient temperature $\left(\mathrm{T}_{e f}\right.$ or the ambient temperature corrected for the effect of wind speed; Siple and Passel 1945) to LCT to determine whether metabolic heat production would be required to maintain the duck's body temperature. If $\mathrm{T}_{e f}$ was less than LCT, we assumed that metabolic heat production was required to maintain body temperature; we then calculated this energy requirement and included it in the final DEE. On the other hand, if $\mathrm{T}_{\text {ef }}$ was greater than the lower critical temperature, we did not include metabolic heat production. Effective temperature was calculated using the relationship derived by Siple and Passel (1945):

$$
\begin{aligned}
T_{e f}= & T_{b}-\left(T_{b}-T_{a}\right) \\
& \times(0.474+0.239 \times \sqrt{u}-0.023 \times u),
\end{aligned}
$$

where $T_{e f}$ is the effective temperature $\left({ }^{\circ} \mathrm{C}\right)$ used for comparison with the lower critical temperature, $T_{b}$ is body temperature $\left({ }^{\circ} \mathrm{C}\right), T_{a}$ is ambient temperature $\left({ }^{\circ} \mathrm{C}\right)$, and $u$ is wind speed $(\mathrm{m} / \mathrm{sec})$.

If $\mathrm{T}_{e f}$ was less than LCT, we used an empirical model to estimate metabolic heat production as a function of temperature and wind speed (Goldstein 1983):

$$
H_{T+u}=a+b \sqrt{u},
$$

where $u$ is wind speed $(\mathrm{m} / \mathrm{sec})$ and $H_{T+u}$ is metabolic heat production (watts). The coefficient $b$ is determined empirically from data summarized by Goldstein (1983) on seven species of birds (body size $13.5-3,860 \mathrm{~g}$ ) by the relation: $b=0.0092 \mathrm{M}^{0.66} \times \Delta \mathrm{T}^{0.32}$, where
$\mathrm{M}$ is body weight in $\mathrm{g}$ and $\Delta \mathrm{T}$ is the difference between lower critical temperature and ambient temperature in ${ }^{\circ} \mathrm{C}$. The coefficient $a$ is determined under conditions of free convection ( $u=0.06 \mathrm{~m} / \mathrm{sec}$ ) by the relation:

$$
a=H_{T}-b \sqrt{0.06},
$$

where $H_{T}$ is an adjusted metabolic rate in watts at ambient temperature (Goldstein 1983). We estimated $H_{T}$ using a heat transfer model proposed by Birkebak (1966) that calculates conductive heat loss from different anatomical regions of the bird to the environment using geometrical representations (e.g., head represented as a sphere, body represented as a cylinder) and heat transfer theory (Appendix; Birkebak 1966). Morphological measures of body dimensions (Fig. 1) can be obtained from the literature (e.g., Belrose 1980, Gauthier 1993) or from measurements of museum specimens. Average values for live Buffleheads $(n=4$, obtained from the Connecticut Waterfowl Trust, Farmington, Connecticut) and Bufflehead study skins $(n=16$, obtained from the Harvard Museum of Comparative Zoology, Cambridge, Massachusetts) are summarized in the Appendix. Also summarized in the appendix are the equations drawn from Birkebak (1966), which were used to calculate metabolic heat production. For these equations, a heat transfer coefficient (k) of $0.102 \mathrm{cal} / \mathrm{cm} /{ }^{\circ} \mathrm{C}$ was used for the entire body surface (Calder and King 1974). The thermal conductance of Common Eider (Somateria mollissima) in water (i.e., wet thermal conductance) has been shown to be $57 \%$ greater than it is in the air (Jenssen et al. 1989); therefore, we used a heat transfer coefficient of $0.160 \mathrm{cal} / \mathrm{cm} /{ }^{\circ} \mathrm{C}$ to calculate heat loss from the ventral body surface to the water. Metabolic heat production was calculated as: $\mathbf{B M R}+\mathbf{Q}_{\text {head }}+\mathbf{Q}_{\text {neck }}+\mathbf{Q}_{\text {breast }}+\mathbf{Q}_{\text {body }}+$ $\mathbf{Q}_{\text {ventral surface, where BMR is basal metabolic }}$ rate and Q is the heat loss term for each body component.

Estimates of additional energetic costs resulting from specific daily activities $\left(\mathrm{EE}_{\text {Activity }}\right)$ were calculated by multiplying the proportion of time spent in a particular activity by the energetic cost of that activity. We used previously reported multiples of BMR, summarized in Table 1, to calculate the energetic costs of activities by multiplying the propor- 

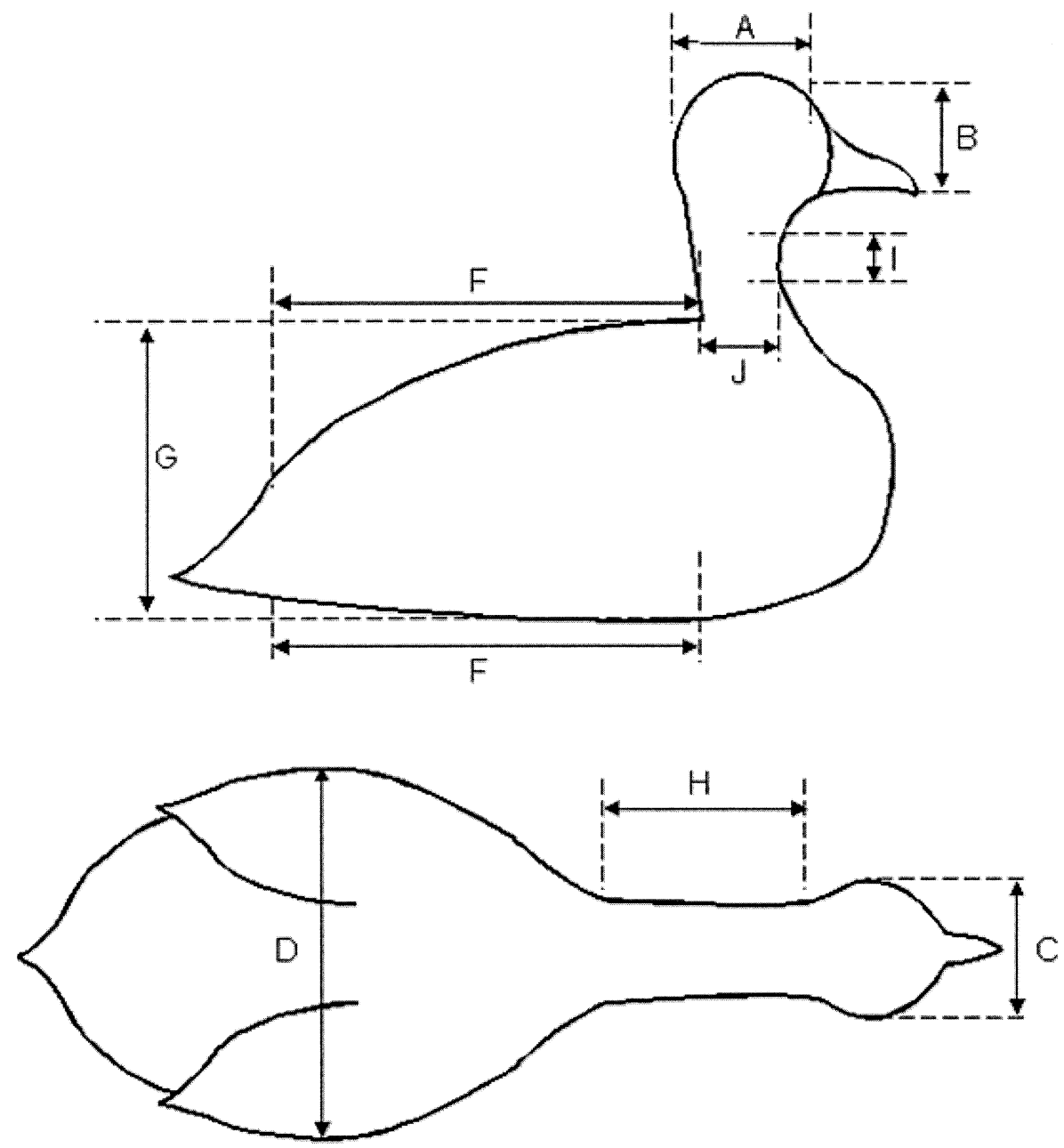

FIG. 1. Body dimension measurement points required for input into the SST model to estimate DEE (see Appendix). $\mathrm{A}=$ head length, $\mathrm{B}=$ head height, $\mathrm{C}=$ head width, $\mathrm{D}=$ body width, $\mathrm{F}=$ body length, $\mathrm{G}=$ body height, $\mathrm{H}=$ neck length, $\mathrm{I}=$ neck width, $\mathrm{J}=$ neck height.

TABLE 1. Energetic costs as a multiple of basal metabolic rate (BMR) of activities used in the site-specific and fixed-cost thermoregulation DEE models.

\begin{tabular}{llrl}
\hline \multicolumn{1}{c}{ Activity } & \multicolumn{1}{c}{ Operational definition } & $\begin{array}{c}\text { Multiple of } \\
\text { BMR }\end{array}$ & \multicolumn{1}{c}{ Reference } \\
\hline Dive & Diving for food & 5.1 & de Leeuw 1996 \\
Surface & Surface and pause between dives & 5.1 & de Leeuw 1996 \\
Look & Peering through the water at the cove bottom & 1.8 & Wooley and Owen 1978 \\
Courtship & Social display toward individual of the opposite gender & 2.4 & Albright et al. 1983 \\
Agonistic & Hostile interaction between two individuals & 1.8 & Wooley and Owen 1978 \\
Swim & Locomotion & 3.5 & Butler 2000 \\
Fly & Locomotion & 12.5 & Wooley and Owen 1978 \\
Preen & Maintenance of feathers & 2.1 & Albright et al. 1983 \\
Alert & Not moving, but actively observing surroundings & 1.8 & Wooley and Owen 1978 \\
Rest & Not moving with bill tucked in feathers & 1.4 & Wooley and Owen 1978 \\
\hline
\end{tabular}


tion of time spent in that activity by the corresponding multiple of BMR. The contribution of physical activity to DEE (Table 2; $E_{\text {Activity }}$ ) was then calculated by summing the energetic costs of all activities in which Buffleheads engaged.

DEE fixed-cost thermoregulation model.Estimates of DEE were calculated using a method that incorporates a fixed cost of thermoregulation (fixed-cost model; Morton et al. 1989). In this model, the thermoregulatory component $\left(\mathrm{EE}_{\text {Thermoreg }}\right)$ is fixed and estimated at $5.9 \mathrm{~kJ} / \mathrm{hr}$ (Morton et al. 1989). Additional energetic costs resulting from specific daily activities ( $\left.\mathrm{EE}_{\text {Activity }}\right)$ were calculated as in the SST model by multiplying the proportion of time spent in a particular activity by the energetic cost of that activity. These two components were then summed to arrive at fixedcost model estimates of DEE.

DEE-habitat correlations.-We identified six Bufflehead wintering habitats within welldefined coves or embayments of the Narragansett Bay estuary. Included were two mesotrophic, rocky- and sandy-bottom embayments (Sheffield Cove: $41^{\circ} 29^{\prime} 41^{\prime \prime} \mathrm{N}, 71^{\circ} 22^{\prime}$ $89^{\prime \prime} \mathrm{W}$; and Mackeral Cove: $41^{\circ} 29^{\prime} 28^{\prime \prime} \mathrm{N}$, $71^{\circ} 20^{\prime} 86^{\prime \prime} \mathrm{W}$ ), two mesotrophic soft-bottom coves (Coggeshal Cove: $41^{\circ} 39^{\prime} 32^{\prime \prime} \mathrm{N}, 71^{\circ}$ $20^{\prime} 52^{\prime \prime} \mathrm{W}$; and Brush Neck Cove: $41^{\circ} 41^{\prime} 47^{\prime \prime}$ $\mathrm{N}, 71^{\circ} 24^{\prime} 48^{\prime \prime} \mathrm{W}$ ), and two eutrophic soft-bottom coves (Apponaug Cove: $41^{\circ} 41^{\prime} 40^{\prime \prime} \mathrm{N}$, $71^{\circ} 28^{\prime} 58^{\prime \prime} \mathrm{W}$; and Watchemoket Cove $41^{\circ}$ $\left.48^{\prime} 00^{\prime \prime} \mathrm{N}, 71^{\circ} 22^{\prime} 75^{\prime \prime} \mathrm{W}\right)$. Cove areas ranged from 18.6 to 86.1 ha, with an average of 42.2 ha. Each cove supported consistent numbers of Buffleheads throughout the winter (November through April); the median flock size at the six sites (determined by bimonthly censuses during the winters of 2001-2002 and 2002-2003) was 18, ranging from 13 to 41 . In winter, Buffleheads spend the majority of their time on the water and tend to favor shallow water habitats $(<3 \mathrm{~m})$ in protected coves (Stott and Olson 1973, Gauthier 1993). They feed by diving to the cove bottom where they consume benthic invertebrates including crustaceans, gastropods, and bivalves (Yocum and Keller 1961, Wiemeyer 1967, Gauthier 1993).

We used focal animal sampling to quantify activities of Buffleheads at each of the study sites during the winters of 2001-2002 and 2002-2003 (Altmann 1974). We completed
965 observations on individual birds, resulting in over $80 \mathrm{hr}$ of activity budget data. Observations were randomly distributed over sample sites and time during the daytime throughout the winter period when ducks were present (November-April). We chose individual ducks at random (i.e., observations began with the $i$ th duck from the left in each flock, where $i$ was a randomly generated number) and observed through a $32-60 \times$ spotting scope or through $10 \times 50$ binoculars for $5 \mathrm{~min}$; behaviors were categorized as dive, surface, look (i.e., peering through the water at the cove bottom), courtship, agonistic, swim, fly, preen, alert, and rest (Table 1). Preening included wing flapping, stretching, and scratching. Gender for each individual was identified when possible, except in rare instances when we were unable to distinguish between females and first-year males that had not yet developed breeding plumage (Carney 1992). Therefore, we report results for "males" (showing breeding plumage) and "females" (includes first year males). Activity data were collected using an observational software program installed on a laptop computer (JWatcher, Animal Behaviour Laboratory, Macquarie University, Australia; http://www.jwatcher. ucla.edu/). Prior to analysis, data were aggregated into the following categories: feeding (dive, surface, look), social (courtship, agonistic), locomotion (swim, fly), maintenance (preen, alert), and resting. Each sampling event at a site consisted of 20-30 five-min observations; final data were averaged by sampling event and by site.

Sensitivity analysis.-We used linear regression analysis of SST model estimates of DEE versus wind speed and feeding behavior, respectively, to assess the relative contribution of each to DEE. First, we estimated DEE using average values of feeding activity across all sites, and plotted DEE versus wind speed over the range of wind speeds recorded during the study (i.e., feeding activity held constant, wind speed varied; regression equation: DEE $=[1.1 \times$ wind speed $]+42.1)$. Second, we estimated DEE using average wind speed and temperature across the sites and plotted DEE versus the proportion of feeding activity (i.e., wind speed held constant, feeding activity varied; regression equation: $\mathrm{DEE}=[43.1 \times$ proportion of time spent feeding] +17.3 ). In each 


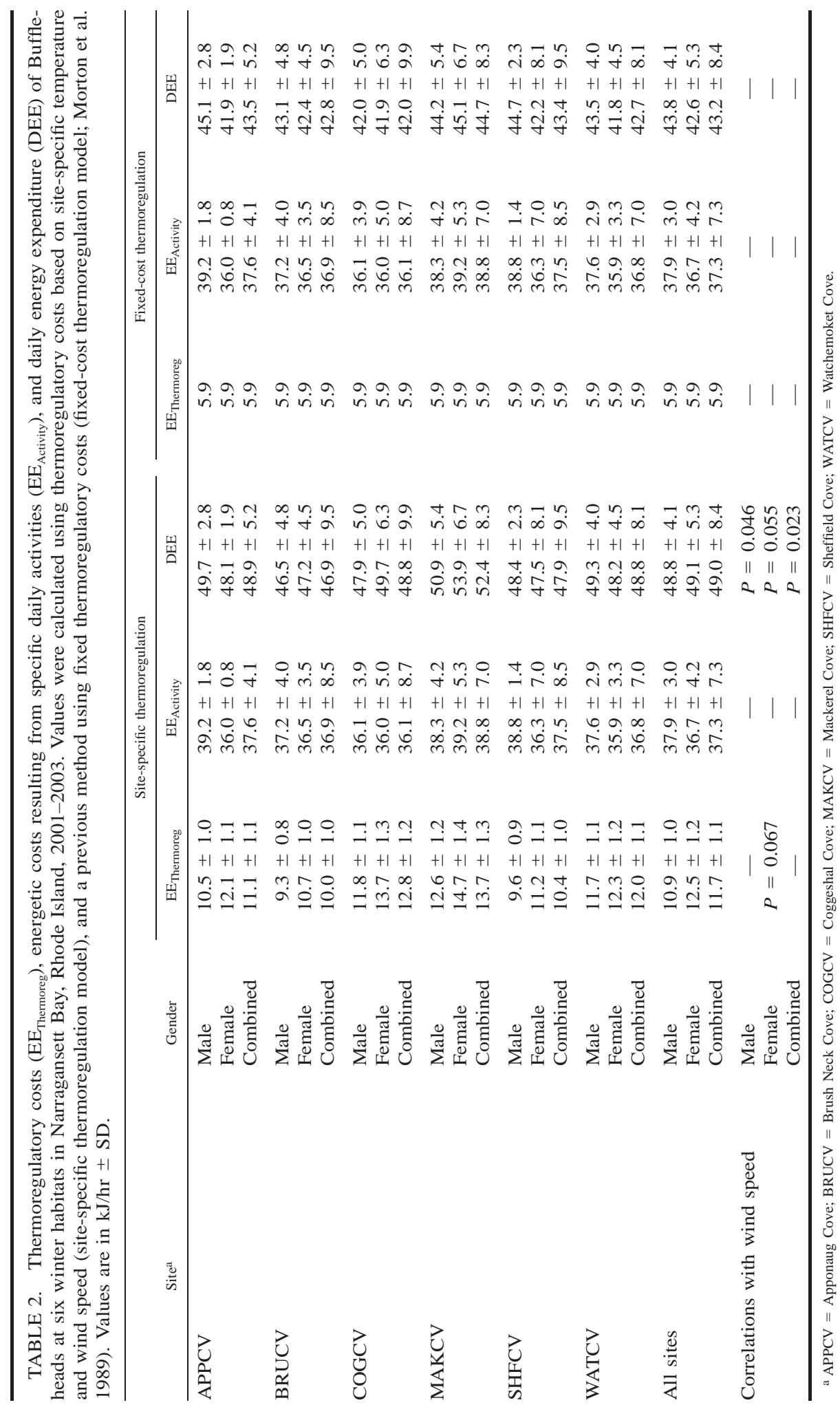


case, we used average values of temperature and all other activities in the model. Regression equations generated from each analysis were used to estimate the relative contribution of wind speed and feeding behavior to DEE. For wind speed, we calculated the average percent increase in DEE per $1 \mathrm{~m} / \mathrm{sec}$ increase in wind speed. For proportion of time spent feeding, we calculated the average percent increase in DEE per 5\% increase in the proportion of time spent feeding.

Statistical analyses.-Differences in the proportion of time spent on different activities by males versus females were investigated using two-tailed Student's $t$-tests on data averaged across all sample sites. Site-specific time budgets were calculated by averaging individual observations by sampling event and then by averaging sampling events by site. Proportions were arcsine-square-root transformed prior to regression analysis (Fowler et al. 1998:87-88). Wind speed and temperature were averaged by sampling event and by site. Regression analysis and analysis of variance were used to assess the influence of environmental conditions on DEE and feeding behavior. Statistical analyses were performed using SAS (SAS Institute, Inc. 2001).

\section{RESULTS}

Estimates of DEE for wintering Buffleheads generated using the SST model averaged 49.0 $\pm 8.4 \mathrm{~kJ} / \mathrm{hr}$, or $1,176 \pm 202 \mathrm{~kJ} / \mathrm{day}$, and differed by up to $12 \%$ among sites (Table 2). The mean thermoregulatory component of DEE ( $\mathrm{EE}_{\text {Thermoreg; }}$; Table 2) was $11.7 \pm 1.1 \mathrm{~kJ} / \mathrm{hr}$ or $23.9 \%$ of total DEE; $\mathrm{EE}_{\text {Thermoreg }}$ increased with increasing wind speed $\left(r^{2}=0.61, P=0.067\right)$. DEE did not differ between males and females; however, thermoregulatory costs were higher for females $($ mean $=12.5 \pm 1.2$ versus $10.9 \pm 1.0 \mathrm{~kJ} / \mathrm{hr}$ for males; $t_{5}=-7.2, P<$ $0.001)$.

The mean DEE (all sites) calculated using the SST model was $13.4 \%$ higher than that calculated using the fixed-cost model (Table 2). The thermoregulatory component of DEE, $5.9 \mathrm{~kJ} / \mathrm{hr}$, composed $13.7 \%$ of total DEE calculated with the fixed-cost model.

Daily energy expenditures of Buffleheads calculated with the SST model increased with increasing wind speed for males $\left(r^{2}=0.67, P\right.$ $=0.046)$, females $\left(r^{2}=0.64, P=0.055\right)$, and
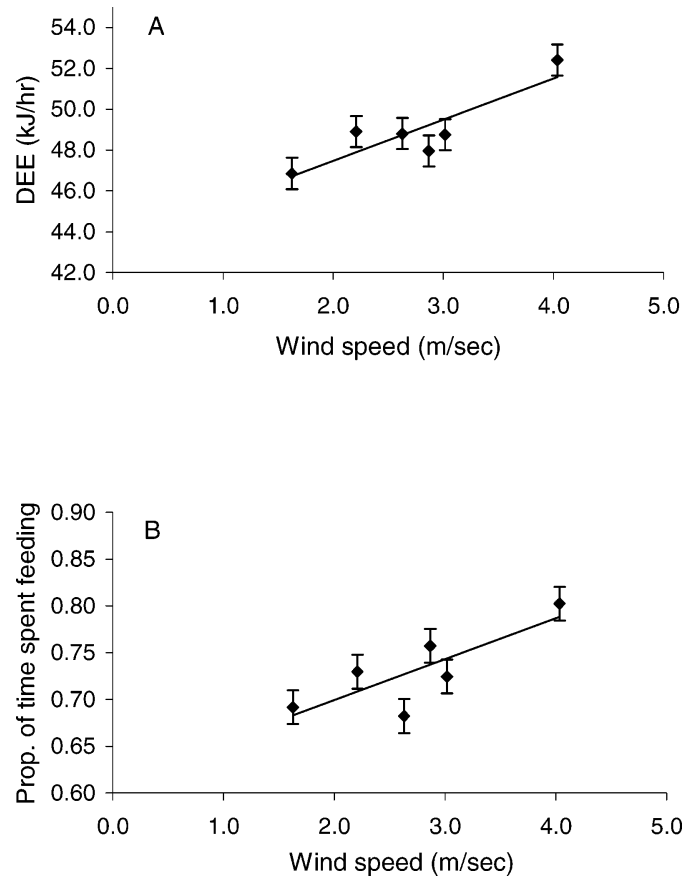

FIG. 2. Correlation of wind speed with (A) DEE and (B) time spent feeding for Buffleheads (males and females combined) wintering at six coastal habitats in Narragansett Bay, Rhode Island, 2001-2003. Wind speeds are means of all sampling sessions conducted at a site. Error bars are $\pm \mathrm{SE}$.

males and females combined $\left(r^{2}=0.76, P=\right.$ 0.023 ; Fig. 2A). The proportion of time spent feeding by Buffleheads also increased with increasing wind speed $\left(r^{2}=0.67, P=0.047\right.$ Fig. 2B). Estimates of DEE that were generated using the fixed-cost model showed no relationship between DEE and wind speed.

Buffleheads spent $75.7 \pm 4.3 \%$ of their time feeding during daylight hours, and females fed more often than males $(77.1 \pm 5.4 \%$ versus $74.2 \pm 6.9 \% ; t_{545}=-2.6, P=0.004$; Table 3). Males, however, spent more of their time engaged in courtship activities $(2.39 \%$ versus $\left.0.43 \% ; t_{545}=7.4, P<0.001\right)$. Males and females (combined) averaged $16.8 \%$ of their time engaged in locomotion and maintenance, and $4.5 \%$ of the time resting (Table 3). Buffleheads at Mackerel Cove spent the greatest proportion of time feeding and the least in all other activities, whereas those at Coggeshal Cove spent the least time feeding and the most in all other activities, except resting. Overall, Buffleheads spent between 0.3 and $2.6 \%$ of 
McKinney and McWilliams • WATERFOWL DEE MODEL

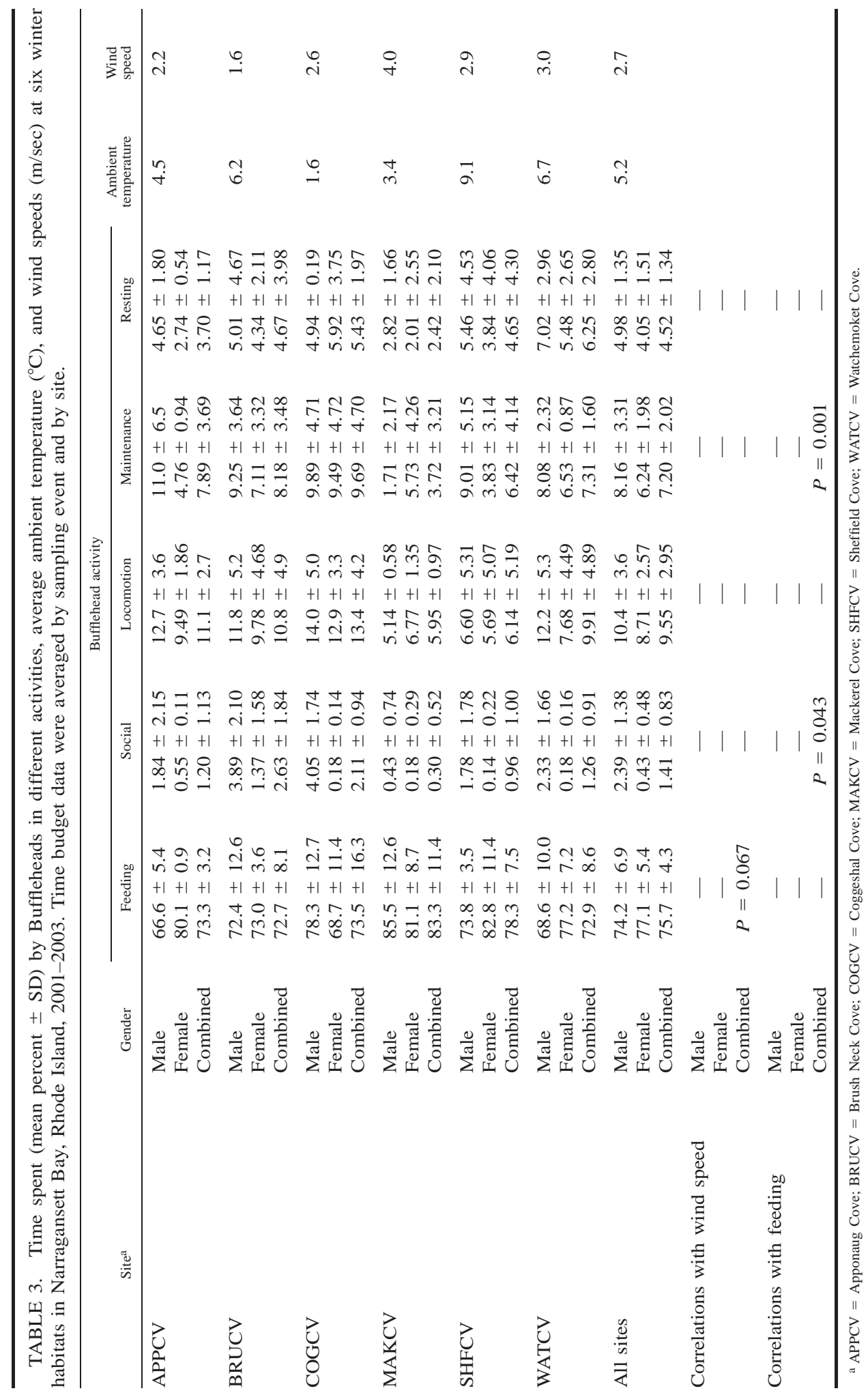


their time in social activities, and this time decreased as the ducks increased feeding $\left(r^{2}\right.$ $=0.71, P=0.043)$. Similarly, the amount of time spent in maintenance activities (range $=$ $3.7-9.7 \%)$ decreased as time spent feeding increased $\left(r^{2}=0.96, P=0.001\right)$.

Sensitivity analysis of model estimates of DEE versus wind speed at constant proportion of time spent feeding showed that a $1 \mathrm{~m} / \mathrm{sec}$ increase in wind speed resulted in a $2.5 \%$ increase in DEE. Analysis of DEE versus the proportion of time spent feeding at constant wind speed showed that a 0.05 increase in proportion of time spent feeding resulted in a $4.5 \%$ increase in DEE.

\section{DISCUSSION}

Our estimates of DEE using the SST model for Buffleheads at the Narragansett Bay wintering sites $(1,175 \pm 202 \mathrm{~kJ} /$ day $)$ are higher than those predicted from the fixed-cost model $(1,036 \pm 202 \mathrm{~kJ} / \mathrm{day})$, which uses a single energetic cost of thermoregulation. Thermoregulatory costs predicted by the SST model constitute up to $28 \%$ of the animal's total DEE and are approximately twice as high on average as that used in the fixed-cost model. DEE estimates for Buffleheads at our sites were also higher than a field metabolic rate predicted by an allometric relation of energy expenditure based on empirical studies (606 kJ/day, non-passerines; Nagy et al. 1999). However, many of the studies from which this relation was derived were carried out in the breeding season in warm ambient temperatures, so our higher DEE estimates may be attributed in part to environmental conditions and the inclusion of thermoregulatory energy costs.

Our model does not include the contribution of heat gained from solar radiation or heat lost through evaporative water loss because these effects are likely relatively small (less than $10 \%$ of heat loss; Scholander et al. 1950, Strunk 1971, Wolf and Walsberg 2000), and were likely similar between our study sites. Nonetheless, these constraints limit the application of our model to comparative, singlespecies studies between habitats that are located in a similar geographic region. It is also important to note that the SST model is limited by the availability of empirically derived energetic equivalents of specific waterfowl be- haviors, as is the fixed-cost model. We applied the model to Buffleheads, but were restricted to using literature-based energetic equivalents that were not specific to that species. Therefore, the DEE estimates presented here, while higher than those calculated from the fixedcost model and from body mass alone, fall well within the probable error of $20-40 \%$ proposed by Weathers et al. (1984) for models that rely on generic energetic equivalents. However, while it would be difficult to argue that our model estimates are more accurate than those calculated from fixed-cost or body mass models, the utility of our model lies in the ability to determine the relative contribution of wind speed, temperature, and specific waterfowl behaviors to DEE across sites with different environmental conditions and levels of activity.

Wintering waterfowl may incur substantial thermoregulatory costs depending on ambient temperatures and the combined effect of wind and cold, and these may lead to increases in DEE. Changes in the relative amounts of activities exhibited by wintering Buffleheads may also alter DEE. In our study, estimates of DEE calculated with the SST model were correlated with wind speed (Fig. 2A). However, feeding activity also increased with increasing wind speed (Fig. 2B), which could also contribute to an increase in DEE. Sensitivity analysis of the effects of increases in wind speed and feeding activity on DEE showed that increases in feeding activity resulted in a relative increase in waterfowl DEE nearly twice that of a corresponding increase in wind speed. Feeding activity may increase because of decreased prey abundance, or because of changes in the availability or energetic content of prey. Further studies at our sites have shown that feeding activity increased with decreasing prey abundance, and also with decreasing prey energy density resulting from changes in available prey species at a site and inter-specific differences in the energetic content of prey (RAM and SRM unpubl. data). However, other factors, such as intra- and inter-specific competition and increased energetic demands, may also influence the amount of feeding activity. Although we are uncertain as to the cause of increases in time spent feeding at our sites, our results show that increased 
feeding activity may have a greater impact than wind exposure on DEE of Buffleheads.

Increased feeding activity may also affect the short- and long-term survival of Buffleheads. For example, if wintering Buffleheads need to spend more time feeding, time for other activities such as courtship and pair formation may be limited (Drent and Daan 1980, Meijer and Drent 1999). Although they exhibit long-term pair bond formation and a high degree of flock synchrony, which results in a relatively small proportion of time spent in social behaviors, courtship and maintenance activities are still important for their overall reproductive success (Robertson et al. 1998). Our results indicate that as Buffleheads at our sites spent more time feeding, they had less time available for maintenance and social behaviors, which may have an impact on both their short- and long-term survival. This, coupled with the greater increases in energetic costs due to feeding activity predicted from model sensitivity analysis, suggests that DEE of wintering waterfowl in harsh climates would be lower in habitats with both high prey density and adequate protection from exposure. For example, sites such as Brush Neck Cove, which had the highest prey abundance (RAM and SRM unpubl. data) and also the lowest thermoregulatory costs for Buffleheads (Table 2), may be better candidate sites for protection as waterfowl wintering habitats compared with sites such as Mackerel Cove, which had low prey abundance and high thermoregulatory costs.

In summary, our SST model estimated DEE as the sum of basal metabolic rate and sitespecific energetic costs of activity and thermoregulation. The primary benefits of the SST model compared to other approaches include its ability to (1) evaluate the effect of thermoregulatory costs on DEE of wintering waterfowl using simple measurements of wind speed and ambient temperature, (2) predict the extent to which the behavior of waterfowl during winter affects DEE, and (3) track changes in DEE over different time scales (i.e., hourly, daily, or seasonally) if the corresponding activity and environmental data are available. Also, because of its ability to estimate sitespecific DEE based on local conditions, the model may be useful in evaluating the quality of waterfowl habitats that have different attri- butes such as prey abundance, or degree of protection from high winds and extreme temperatures. However, further studies will be needed to establish the independence of behavioral responses to environmental conditions from the primary effect of the conditions themselves on the DEE of resident waterfowl before model estimates can be used in habitat assessment.

\section{ACKNOWLEDGMENTS}

We would like to thank K. Bannick and B. Timm for assistance collecting field data. Access to Bufflehead study skins at the Harvard Museum of Comparative Zoology was obtained with the kind assistance of J. Trimble and A. Pirie. We also thank K. Appler and the Connecticut Waterfowl Trust for access to live birds, and D. T. Blumstein, C. S. Evans, and J. C. Daniel for assistance with behavioral data analysis. S. Walters, S. A. Ryba, C. Wigand, and T. R. Gleason provided insightful comments on the manuscript. We also thank M. R. Miller and two anonymous referees for thoughtful comments on an earlier version of this paper. Mention of trade names or commercial products in this report does not constitute endorsement or recommendation. Although the research described in this article has been funded wholly by the U.S. Environmental Protection Agency, it has not been subjected to Agency-level review. Therefore, it does not necessarily reflect the views of the Agency. This paper is the Office of Research and Development, National Health and Environmental Effects Research Laboratory, Atlantic Ecology Division contribution number AED-04074.

\section{LITERATURE CITED}

Albright, J. J., R. B. Owen, JR., AND P. O. Corr. 1983. The effects of winter weather on the behavior and energy reserves of Black Ducks in Maine. Transactions of the Northeast Section of the Wildlife Society 40:118-128.

Altmann, J. 1974. Observational study of behavior: sampling methods. Behaviour 49:227-265.

BAKKEN, G. S. 1992. Measurement and application of operative and standard operative temperature in ecology. American Zoologist 32:194-216.

Baldassarre, G. A., S. L. Paulus, A. TAsmisier, And R. D. Titman. 1988. Workshop summary: techniques for timing activity of wintering waterfowl. Pages 181-188 in Waterfowl in winter: selected papers from symposium and workshop held in Galveston, Texas, 7-10 January 1985 (M. W. Weller, Ed.). University of Minnesota Press, Minneapolis.

Belrose, F. 1980. Ducks, geese, and swans of North America, 3rd ed. Stackpole Books, Harrisburg, Pennsylvania.

BennetT, J. W. And E. G. Bolen. 1978. Stress response in wintering Green-winged Teal. Journal of Wildlife Management 42:81-86. 
BiRKeBAK, R. C. 1966. Heat transfer in biological systems. International Reviews of General and Experimental Zoology 2:269-344.

Brodsky, L. M. AND P. J. WeAtherheAd. 1985a. Diving by wintering Black Ducks: an assessment of atypical foraging. Wildfowl 36:72-76.

Brodsky, L. M. AND P. J. WeATHERHEAD. 1985b. Variability in behavioural response of wintering Black Ducks to increased energy demands. Canadian Journal of Zoology 63:1657-1662.

BUtLER, P. J. 2000. Energetic costs of surface swimming and diving of birds. Physiological and Biochemical Zoology 73:699-705.

Calder, W. A. AND J. R. KING. 1974. Thermal and caloric relations of birds. Avian Biology 4:259413.

CARnEY, S. M. 1992. Species, age, and sex identification of ducks using wing plumage. U.S. Fish and Wildlife Service, Washington, D.C.

DE LEEUW, J. J. 1996. Diving costs as a component of daily energy budgets of aquatic birds and mammals: generalizing the inclusion of dive-recovery costs demonstrated in Tufted Ducks. Canadian Journal of Zoology 74:2131-2142.

DRENT, R. H. AND S. DAAN. 1980. The prudent parent: energetic adjustments in avian breeding. Ardea 68:225-252.

EtTinger, A. O. And J. R. King. 1980. Time and energy budgets of the Willow Flycatcher (Empidonax traillii) during the breeding season. Auk 97: 533-546.

Fowler, J., L. Cohen, AND P. JARVIS. 1998. Practical statistics for field biology. John Wiley \& Sons, New York.

Fredrickson, L. H. AND R. D. Drobney. 1979. Habitat utilization by postbreeding waterfowl. Pages 239272 in Waterfowl and wetlands: an integrated review (T. A. Bookhout, Ed.). LaCrosse Printing, LaCrosse, Wisconsin.

GAuthiER, G. 1993. Bufflehead (Bucephala albeola). The Birds of North America, no. 67.

Goldstein, D. L. 1983. Effect of wind on avian metabolic rate with particular reference to Gambel's Quail. Physiological Zoology 56:485-492.

Hickey, T. E. AND R. D. Titman. 1983. Diurnal activity budgets of Black Ducks during their annual cycle on Prince Edward Island. Canadian Journal of Zoology 61:743-749.

Jenssen, B. M., M. EkKer, And C. BeCh. 1989. Thermoregulation in winter-acclimatized Common Eiders (Somateria mollissima) in air and water. Canadian Journal of Zoology 67:669-673.

Jorde, D. G., G. L. Krapu, R. D. Crawford, and M. A. DAY. 1984. Effects of weather on habitat selection and behavior of Mallards wintering in $\mathrm{Ne}$ braska. Condor 86:258-265.

Kendeigh, S. C. 1949. Effect of temperature and season on energy resources of the English Sparrow. Auk 66:113-127.

Kendeigh, S. C., V. R. Dol'niK, And V. M. Gavrilov. 1977. Avian energetics. Pages 127-204 in Granivorous birds in ecosystems: their evolution, populations, energetics, adaptations, impact, and con- trol (J. Pinowski and S. C. Kendeigh, Eds.). Cambridge University Press, New York.

Koplin, J. R., M. W. Collopy, A. R. Bammann, And H. LeVEnson. 1980. Energetics of two wintering raptors. Auk 97:795-806.

McNAB, B. K. 2003. The energetics of New Zealand's ducks. Comparative Biochemistry and Physiology A 135:229-247.

MeiJer, T. AND R. H. Drent. 1999. Re-examination of the capital and income dichotomy in breeding birds. Ibis 141:399-414.

Miller, M. R. 1985. Time budgets of Northern Pintails wintering in the Sacramento Valley, California. Wildfowl 36:53-64.

Morton, J. M., A. C. Fowler, AND R. L. KirkPatrick. 1989. Time and energy budgets of American Black Ducks in winter. Journal of Wildlife Management 53:401-410.

Nagy, K. A., I. A. Girard, and T. K. Brown. 1999. Energetics of free-ranging mammals, reptiles, and birds. Annual Reviews of Nutrition 19:247-277.

NiLSSON, L. 1970. Food-seeking activity of south Swedish diving ducks in the non-breeding season. Oikos 21:145-154.

PARKer, H. AND H. Holm. 1990. Patterns of nutrient and energy expenditure in female Common Eiders nesting in the high arctic. Auk 107:660-668.

Paulus, S. L. 1984. Activity budgets of nonbreeding Gadwalls in Louisiana. Journal of Wildlife Management 48:371-380.

Paulus, S. L. 1988. Time-activity budgets of nonbreeding Anatidae: a review. Pages 135-152 in Waterfowl in winter: selected papers from symposium and workshop held in Galveston, Texas, 7-10 January 1985 (M. W. Weller, Ed.). University of Minnesota Press, Minneapolis.

PeARSON, O. P. 1954. The daily energy requirements of a wild Anna Hummingbird. Condor 56:317322.

Porter, W. P. AND D. M. GAtes. 1969. Thermodynamic equilibria of animals with environment. Ecological Monographs 39:227-244.

Quinlan, E. E. AND G. A. Baldassarre. 1984. Activity budgets of non-breeding Green-winged Teal on playa lakes in Texas. Journal of Wildlife Management 48:838-845.

Rave, D. P. and G. A. Baldassarre. 1989. Activity budgets of Green-winged Teal wintering in coastal wetlands of Louisiana. Journal of Wildlife Management 53:753-759.

Robertson, G. J., F. Cooke, R. I. Goudie, And W. S. BoYD. 1998. The timing of pair formation in Harlequin Ducks. Condor 100:551-555.

SAS Institute, InC. 2001. SAS for Windows, ver. 6.12. SAS Institute, Inc., Cary, North Carolina.

Schartz, R. L. AND J. L. Zimmerman. 1971. The time and energy budget of the male Dickcissel (Spiza americana). Condor 73:65-76.

Schmidt-Nielsen, K. 1997. Animal physiology: adaptation and environment, 5th ed. Cambridge University Press, Cambridge, United Kingdom.

SCHOlander, P. F., R. Hock, V. WALters, F. Johnston, AND L. IRVING. 1950. Heat regulation in some arc- 
tic and tropical mammals and birds. Biological Bulletin 99:225-236.

Siple, P. A. AND C. F. PASSEl. 1945. Measurements of dry atmospheric cooling in subfreezing temperatures. Proceedings of the American Philosophical Society 89:177-199.

StiLes, F. G. 1971. Time, energy, and territoriality of the Anna Hummingbird (Calypte anna). Science 173:818-821.

Stott, R. S. AND D. P. Olson. 1973. Food-habitat relationship of sea ducks on the New Hampshire coastline. Ecology 54:996-1007.

StrunK, T. H. 1971. Heat loss from a Newtonian animal. Journal of Theoretical Biology 33:35-61.

Turnbull, R. E. And G. A. Baldassarre. 1987. Activity budgets of Mallards and American Wigeon wintering in east-central Alabama. Wilson Bulletin 99:457-464.

WALSBERG, G. E. 1977. Ecology and energetics of contrasting social systems in Phainopepla nitens (Aves: Ptilogonatidae). University of California Publications in Zoology, no. 108, Berkeley.
Walsberg, G. E. 1983. Avian ecological energetics. Avian Biology 7:138-172.

Weathers, W. W., W. A. Buttemer, A. M. Hayworth, AND K. A. NAGY. 1984. An evaluation of timebudget estimates of daily energy expenditure in birds. Auk 101:459-472.

WiEMEYER, S. N. 1967. Bufflehead food habits, parasites, and biology in northern California. M.Sc. thesis, Humboldt State College, Arcata, California.

Wolf, B. O. And G. E. Walsberg. 2000. The role of plumage in heat transfer processes of birds. American Zoologist 40:575-584.

WoOley, J. B., JR. AND R. B. Owen, JR. 1978. Energy costs of activity and daily energy expenditure in the Black Duck. Journal of Wildlife Management 42:739-745.

Yocum, C. F. AND M. Keller. 1961. Correlation of food habits and abundance of waterfowl, Humboldt Bay, California. California Fish and Game 47:41-54.

APPENDIX. Variables used to calculate heat transfer, an adjusted metabolic rate at ambient temperature, using a heat transfer model proposed by Birkebak (1966). Representative values are from repeated measurements on live and preserved Buffleheads from northeastern estuaries. Equations are taken from Birkebak $(1966) ; k$ is the heat transfer coefficient, $\Delta \mathrm{T}$ is the difference between body temperature $\left(39^{\circ} \mathrm{C}\right)$ and ambient temperature.

\begin{tabular}{|c|c|c|c|}
\hline Variable & Symbol & Equation & $\begin{array}{l}\text { Representative } \\
\text { value }(\mathrm{cm} \pm \mathrm{SD})\end{array}$ \\
\hline Head length & A & - & $5.9 \pm 0.4$ \\
\hline Head height & B & - & $5.0 \pm 0.8$ \\
\hline Head width & $\mathrm{C}$ & - & $3.2 \pm 0.4$ \\
\hline Body width & $\mathrm{D}$ & - & $9.1 \pm 0.9$ \\
\hline Body length & $\mathrm{F}$ & - & $18.2 \pm 1.1$ \\
\hline Body height & $\mathrm{G}$ & - & $6.3 \pm 0.6$ \\
\hline Neck length & $\mathrm{H}$ & - & $2.0 \pm 0.3$ \\
\hline Neck width & I & - & $2.9 \pm 0.4$ \\
\hline Neck height & $\mathrm{J}$ & - & $2.9 \pm 0.4$ \\
\hline Integument depth-body & $\Delta \mathrm{X}_{\text {body }}$ & - & $0.4 \pm 0.1$ \\
\hline Integument depth-head & $\Delta \mathrm{X}_{\text {head }}$ & - & $0.7 \pm 0.2$ \\
\hline Integument depth-neck & $\Delta \mathrm{X}_{\text {neck }}$ & - & $0.7 \pm 0.2$ \\
\hline Inner radius of body & $r_{i \text { body }}$ & $r_{i b o d y}=(D+G) / 4$ & $3.9 \pm 0.5$ \\
\hline Inner radius of head & $r_{i \text { head }}$ & $r_{\text {ihead }}=(B+C) / 4$ & $2.1 \pm 0.4$ \\
\hline Inner radius of neck & $r_{i \text { neck }}$ & $r_{\text {ineck }}=(I+J) / 2$ & $2.9 \pm 0.6$ \\
\hline Length of body & $\mathrm{L}_{\text {body }}$ & $L_{b o d y}=F-(D+G) / 2$ & $10.5 \pm 0.5$ \\
\hline Length of neck & $\mathrm{L}_{\text {neck }}$ & $L_{\text {neck }}^{\text {oody }}=H-(I+J) / 2$ & $0.9 \pm 0.1$ \\
\hline Outer radius of body & $r_{o \text { body }}$ & $r_{\text {Obody }}=r_{i b o d y}+\Delta X_{b o d y}$ & $4.6 \pm 0.8$ \\
\hline Outer radius of head & $\mathrm{r}_{\mathrm{o} \text { head }}$ & $r_{\text {Ohead }}=r_{\text {ihead }}+\Delta X_{\text {head }}$ & $2.8 \pm 0.7$ \\
\hline Outer radius of neck & $\mathrm{r}_{\mathrm{o} \text { neck }}$ & $r_{\text {Oneck }}=r_{\text {ineck }}+\Delta X_{\text {neck }}$ & $6.8 \pm 1.1$ \\
\hline Area of ventral surface & $\mathrm{A}_{\mathrm{vs}}$ & $A_{v s}=L_{b o d y} \times 2 r_{\text {Obody }}$ & $96.0 \pm 21.6$ \\
\hline Heat loss from head & $Q_{\text {head }}$ & $\begin{array}{l}Q_{\text {head }}=\left(2 \pi \times r_{\text {Ohead }} \times r_{\text {ihead }} \times k \times \Delta T\right) / \\
\quad\left(r_{\text {Ohead }}-r_{\text {ihead }}\right)\end{array}$ & - \\
\hline Heat loss from neck & $Q_{\text {neck }}$ & $Q_{\text {neck }}=\left(2 \pi \times L_{\text {neck }} \times k \times \Delta T\right) /\left[\ln \left(r_{\text {Oneck }} / r_{\text {ineck }}\right)\right]$ & - \\
\hline Heat loss from breast & $\mathrm{Q}_{\text {breast }}$ & $\begin{array}{l}Q_{\text {breast }}=\left(2 \pi \times r_{\text {obody }} \times r_{\text {ibody }} \times k \times \Delta T\right) / \\
\quad\left(r_{\text {Obody }}-r_{\text {ibody }}\right)\end{array}$ & - \\
\hline Heat loss from body & Q body & $Q_{\text {body }}=\left(2 \pi \times L_{\text {body }} \times k \times \Delta T\right) /\left[\ln \left(r_{\text {Obody }} / r_{\text {ibody }}\right)\right]$ & - \\
\hline $\begin{array}{l}\text { Heat loss from ventral } \\
\text { surface }\end{array}$ & $\mathrm{Q}_{\mathrm{vs}}$ & $Q_{v s}=k \times A_{d s} \times\left(T_{b}-T_{a}\right)$ & - \\
\hline Heat loss from tail & $\mathrm{Q}_{\text {tail }}$ & $\mathrm{Q}_{\text {tail }} \cong Q_{\text {breast }}$ & - \\
\hline
\end{tabular}

